\title{
Järjen päämääräsokeus
}

Max Horkheimer (2008). Välineellisen järjen kritiikki. Suom. OlliPekka Moisio \& Veikko Pietilä. Alkuperäinen teos Eclipse of Reason (1947). Tampere: Vastapaino. 265 sivua.

Millainen on hyvä ihminen? Kaikista piirteistä ei olla yhtä mieltä, mutta vaatimusta järkevyydestä harvoin kyseenalaistetaan. Kyky ja uskallus järjen käyttämiseen ilman ulkopuolista johdatusta on pitkään ollut autonomisen ja täysi-ikäisen ihmisen perusvaatimus. Välineellisen järjen kritiik$k i$-teoksen alkuperäinen nimi Eclipse of Reason kuvaa valistuksesta alkunsa saaneen järjen valon pimennystä 1900-luvun alkupuoliskon hirmuteoissa ja sodissa. Järki, jonka piti vapauttaa ihmiskunta suvaitsemattomuudesta, taikauskoista, mytologioista, sorrosta ja fundamentalismista, valjastettiin teknologian avustuksella barbaarisen tuhokoneiston palvelukseen ja ihmisten massamuotoiseen tuhoamiseen. Tuhokoneiston palveluksessa järki kääntyi itseään ja sen synnyttäneitä valistusihanteita vastaan.

Välineellisen järjen kritiikki etsii syitä sivistyneen maailman barbaariseen taantumiseen tälle ominaisesta järkevyyden muodosta. Kysymys järjestä onkin perustava kaikelle ihmisenä olemiselle, jota perustellaan sen "järkevyydellä’. Järjellä on erityinen yhteys pedagogiseen ajatteluun, sillä juuri koulutuksen ja kasvatuksen on ollut määrä lunastaa valistuksen optimistiset lupaukset ihmiskunnan edistymisestä. Harvoin kuitenkaan tulemme arkisessa aherruksessamme ajatelleeksi. mistä järjessä on oikeastaan perimmiltään kysymys. Jär- kevyys on jotain niin ilmeistä, ettei oikeastaan ole järkevää sitä sen enempää pohtia. Ketä se hyödyttäisi? Vai pitäisikö sittenkin miettiä, millainen järkevyyden muoto on sisäänrakennettu sivilisaatioomme?

Maineikkaan Frankfurtin kriittisen koulukunnan perustajahahmo, Max Horkheimerin (18951973) otti tämän asiakseen ja huomasi, että järkemme on subjektivoitunut, välineellistynyt ja kaavoihin kangistunut. Viimeisten vuosisatojen aikana järki on rajattu koskemaan subjektiivisen hyödyn tavoittelun välineiden laskelmointia. Aikamme subjektiivinen järki on viime kädessä kykyä laskelmoida todennäköisyyksiä ja sovittaa laskelmien pohjalta oikeat keinot annettuihin päämääriin. Järkevyys määrittyy siis subjektiivisen ja käytännöllisen hyödyllisyyden kautta.

Välineellisen järjen kannalta mikään päämäärä ei voi olla itsessään arvokas. Ajatus itseisarvoista on jäänyt järkevän keskustelun ulkopuolelle. Toisen päämäärän paremmuudesta suhteessa toiseen ei voi käydä järkevää keskustelua, sillä tällainen ymmärretään kysymykseksi mieltymyksistä ja mausta. Elämän päämääräkysymykset jäivät uskonnon ja tieteen arvovaltataisteluissa uskonnolle. Laihan sovun johdosta järjestä ja tieteestä tuli hampaaton päämääräkysymyksien edessä ja uskonto pääsi turvaan filosofien rationaa- lisilta hyökkäyksiltä, vaikkakin menetti samalla maallista vaikutusvaltaansa.

Nykyisen järjen kriisi on Horkheimerin mukaan juuri siinä, ettei ihmisen elämän päämääräkysymyksistä keskustelua järkevästi. Päämäärät voivat rationaalisen keskustelun ulottumattomissa määräytyä mielivaltaisten muotien, ideologioiden ja etupyyteiden tuoksinassa. Tämä jättää ovet auki erilaisten mytologisten ajattelutapojen luikertelemiselle toimintamme ytimiin, mistä fasismi oli tyyppiesimerkki. Myös hirmuvalta, julmuus ja sorto voivat olla välineellisen järjen subjektiivisessa katsannossa "järkeviä" toimintamalleja, kun mitään objektiivista mittapuuta järkevyydelle ei ole. Järki ei kuitenkaan aina ole ollut itsetuhoista ja päämääräsokeaa.

Objektiivinen järki käsitti järkevyyden sekä yksilöllisessä tietoisuudessa että objektiivisessa todellisuudessa. Platonin ja Aristoteleen ajattelun tapaiset suuret filosofiat loivat kattavia teorioita todellisuudesta. Näissä suurissa teorioissa pohdittiin myös ihmisen elämän tavoitteita suhteessa järjestelmän kokonaisuuteen (totaliteettiin). Objektiivisen järjen mittapuut tulivat filosofisen teorian kokonaisuudesta ja järkevyyden keskeinen piirre oli sopusointu kokonaisuuden kanssa. Kokonaisuus loi ihmiselle pelkän subjektiivisen edun ylittävän merkitysnäkökentän, johon suhteessa järjellisyys määräytyi. Objektiivinen järki ei pitäytynyt keinojen laskelmoinnissa, vaan paino oli pikemminkin hyvän elämän ja yhteiskun- 
nan päämääräkysymysten filosofisessa pohdinnassa.

Objektiivisen järjen valuttua tyhjäksi sisällöstä, jäi jäljelle tyhjät kuoret ja järjestä tuli kaavamaista (formalized reason). Kaavamainen järki kääntyy empiiristen tieteen menetelmien puoleen löytääkseen järkeviä menettelytapoja. Kysyttäessä, miksi empiirinen havainnointi on ainoa totuuden tae, vetoavat positivistiset tiedemiehet taas havainnointiin. Noidankehä on valmis ja kaavamaisen järjen ihanteena toimivasta positivismista on tullut yhtä dogmaattinen kuin autoritääriset ja mytologiset uskomusjärjestelmät, joita vastaan sen piti taistella. Insinöörivitsit kuvaavat huumorin keinoin todellisuutta pikkutarkasti tieteen ja tekniikan menettelytapojen avulla hahmottavaa insinööriä. Kaavamainen opettaja pakottaa omat havaintonsa ja opiskelijoiden yksilöllisyyden omaan tieteellisen teoriansa mukaiseksi. Kaavamaisesti toimivan lääkärin mukaan potilas on terve niin kauan, kun vaivasta ei ole tieteellisiä todisteita ja tutkimustietoa.
Välineellisen ja kaavamaisen järjen lävistämä teknokraattinen asenne ei ole vieras myöskään pedagogiselle ajattelulle. Ralph Tylerin rationalistinen opetussuunnitelmateoria lienee tyyppiesimerkki tästä. Kasvatuksen välineellistymisestä ja kaavoihin kangistumisesta kuvaa kilpailukykypolitiikka, jossa koulutuksen tehtävä on yhä selvemmin taloudellis-teknisen kilpailukyvyn lisääminen ja ylläpitäminen. Välineelliselle järjelle tyypilliseen tapaan, kilpailukykypäämäärää ei ole tarpeen erikseen perustella, eikä päämääräkeskustelulle rationaalista kieltä varsinaisesti olisikaan. Sivistyksen itseisarvoiset eettiset ihanteet on alistettu kilpailukyvyn raadollisille tehokkuus- ja tuottavuusvaateille, eikä itseisarvoista puhumisella tunnu olevan käytäntöjen valitaan vaikuttavaa merkitystä. Välineellistyessään sivistys on kadottanut perinteistä sisältöään, joka nojasi itseisarvoisten päämäärien ajatukseen. Järkevänä tai ylipäätään mahdollisena koulutuspolitiikkana nähdään kilpailukykyä lisäävät tai ylläpi- tävät valinnat.

Hyvien klassikoiden tavoin Välineellisen järjen kriittiikki ei ole menettänyt ajankohtaisuuttaan. Alkujaan vuonna 1947 julkaistun teoksen ajankohtaisuuden lisääntyminen osoittaa melkein hämmentävän tarkkaa ennustamiskykyä. Kirjan suomentaminen on kulttuuriteko, joka tukee kasvatusfilosofejakin kiinnostavan Frankfurtin koulukunnan kriittisen teorian tunnettuuden lisääntymistä Suomessa. Kirja on tärkeä lisä suomenkielisten filosofian klassikoiden joukkoon ja sen peruskysymyksenasettelun merkittävyys hakee vertaistaan. Kirjaan liitetty Horkheimerin essee Järjen loppu, joka ei kuulunut alkuperäiseen englanninkieliseen laitokseen, tukee temaattista kokonaisuutta. Olli-Pekka Moision laatimat jälkisanat ovat lukijalle arvokkaana apuna valottamassa tarkastelun kontekstia.

\section{JANI PULKKI}

